\title{
Effectiveness of mindfulness-based cognitive therapy on locus of control and achievement motivation in students with learning problems
}

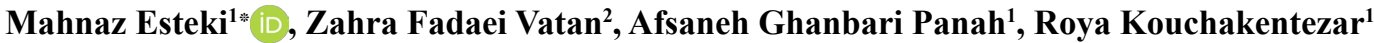 \\ 1. Assistant Professor of Department of Psychology, Faculty of Psychology, Islamic Azad University, Central Branch, Tehran, Iran \\ 2. PhD Student of Psychology and Education of Children with Special Needs, Islamic Azad University, Central Branch, Tehran, Iran
}

Recieved: 17 May 2019

Revised: 5 Jan. 2020

Accepted: 13 Jan. 2020

Keywords

Mindfulness-Based cognitive therapy Achievement motivation

Locus of control

Learning problems

Corresponding author

Mahnaz Esteki, Department of Psychology, Faculty of Psychology, Islamic Azad University, Central Branch, Sohanak, Qaem town, Tehran

Email: P.esteki@gmail.com

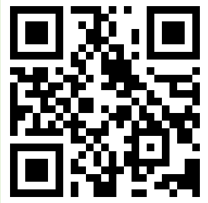

\section{Abstract}

Introduction: The present study aimed at studying the effect of mindfulness-based cognitive therapy on the locus of control and achievement motivation in students with learning problems.

Methods: This research method is a semi-experimental with pretest-posttest and control group design. The population was all Tehran's first restrict middle school girl students. Research samples consisted of 30 students who selected to participate in the study according to the convenience judgmental sampling method. After taking identical test of Rotter's Locus of Control Scale, Herman's achievement motivation questionnaire (HAMQ), and Colorado Learning Difficulties Questionnaire (CLDQ), Participants were then divided randomly into experimental and control groups (each group=15). The eexperimental group received mindfulness-based cognitive therapy of 20 sessions, but control group did not receive any intervention. Follow-up assessment performed three months after ending sessions. Data was analyzed through covariance analysis (ANCOVA).

Results: Research findings indicated that mindfulness-based cognitive therapy changes the locus of control from external to internal. mindfulness-based cognitive therapy is an effective method to enhance internal locus of control and self-esteem. Besides, findings indicated that Mindfulness-Based Cognitive Therapy increases achievement motivation. This intervention method was also an effective method to enhance achievement motivation. Conclusion: Research results suggest that trainers, teachers, and psychologists administer these intervention methods for personal and educational improvement in the learning of disabled students.

Citation: Esteki M, Fadaei Vatan Z, Ghanbari Panah A, Kouchakentezar R. Effectiveness of mindfulness-based cognitive therapy on locus of control and achievement motivation in students with learning problems. Advances in Cognitive Sciences. 2020;21(4):94-102. 


\title{
اثربخشى شناخت درمانى مبتنى بر ذهن آكاهى بر منبع كنترل و انكيزش بيشرفت دانش آموزان داراى مشكلات يادكيرى
}

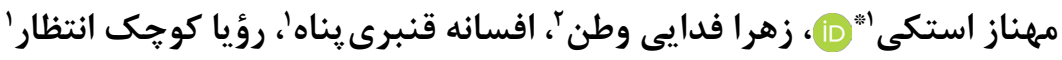

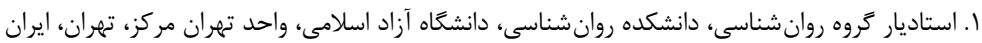

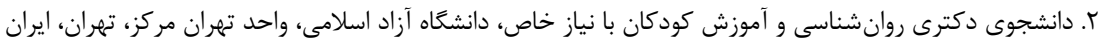

\section{os}

مقلدمه: هدف از يروهش حاضر، بررسى اثربخشى شناخت درمانى مبتنى بر ذهن آكاهى بر منبع كنترل و انكيزش ي بيشرفت دانش آموزان داراى مشكلات يادكيرى بود.

دريافت:

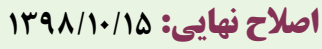

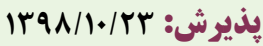
روش كار: يروهش حاضر نيمه آزمايشى با طح بيش آزمون_يٌ آزمون با كروه كنترل بود. جامعه آمارى شامل كليه دانش آموزان دختر مقطع متوسطه اول شهر تهران بود. نمونه كيرى به روش در دسترس، از يكى از مدارس واقع در منطقه ا تهران صورت كرفت. بدين منظور تعداد ·ץ نفر از دانش آموزانى كه بالاترين نمره را در يرسشنامه مشكلات يادكيرى Colorado داشتند انتخاب و به صورت تصادفى در دو كروه آزمايش و كنترل كمارده شدند. آزمودنى ها به يرسشنامه منبع كنترل Rotter و انگيزش يِشرفت پاسخ دادند. آزمودنى هاى گروه آزمايش به مدت •r جلسه تحت آموزش بر مبناى

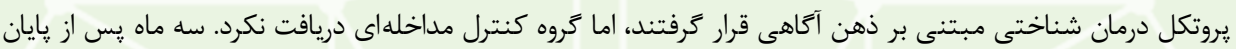
جلسات آزمون بِيخيرى انجام شد. دادها با استفاده از آزمون تحليل كوواريانس تجزيه و تحليل شد. يافته ها: يافته ها نشان داد كه روش مداخله شناخت درمانى مبتنى بر ذهن آكاهى موجب تغيير منبع كنترل از بيرونى به درونى در دانش آموزان داراى مشكلات يادكيرى شد. همجنين يافتهها نشان داد كه اين روش موجب افزايش انخيزش بيشرفت در دانش آموزان داراى مشكلات يادكيرى شد. نتيجهَّيرى: آموزش ذهن آكاهى به دانش آموزان داراى مشكلات يادكيرى، مداخلهاى مؤثر براى افزايش منبع كنترل درونى و انحَيزش مى باشد. بر مبناى نتايج اين يثوهش مى توان به معلمان، مشاوران و روانشناسان آموزشخاهى بِيشنهاد نمود كه با استفاده از اين روش هاى درمانى در بهبود مهارت هاى فردى و يادكيرى دانش آموزان بكوشند.

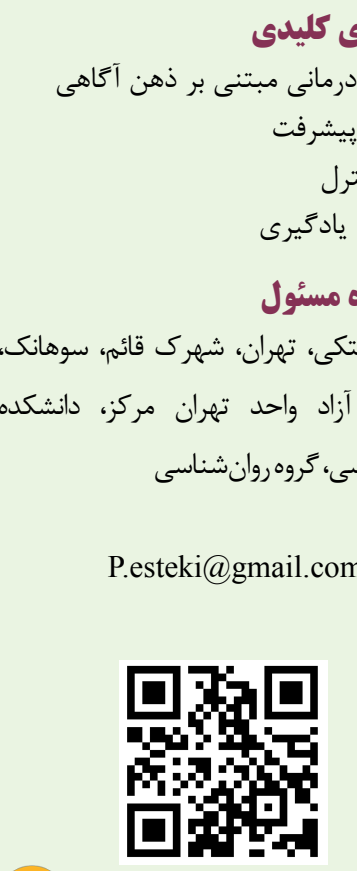

do

doi.org/10.30699/icss.21.4.94

مقلدمه

مشكلات يادَيرى يك اصطلاح كليدى براى مشكلات تحصيلى با يادَيرى اشاره دارد. اصطلاح مشكلات يادَيرى معمولاً مشكلات يادگيرى عمومى و طولانى مدت را كه اغلب با زمينه آموزشى خاصى ريشههاى متفاوت است. اين اصطلاح شامل كمبودهاى يادگيرى و در ارتباط هستند، نشان مى دهد ( (1). همجنين مشكلات يادگيرى يكى عملكرد يايين تحصيلى مانند خواندن، هجى كردن و اختلالات رياضى

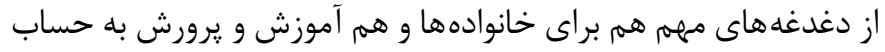
مىشود. در نتيجه، تعريف هاى متفاوتى وجود دارد كه تلاش مى كند بين مى آيد. تأثير اين مشكلات بر تحصيل اين دانش آموزان قابل توجه است اشكال خاص و عمومى اين مشكل تفاوت ايجاد كند يا به ثبات مشكلات 
با انگيزه پيشرفت بالاتر، جديت و پييگيرى بيشترى در تحصيل دارند

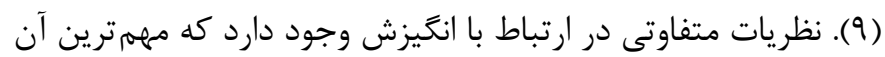

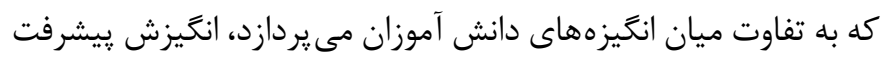

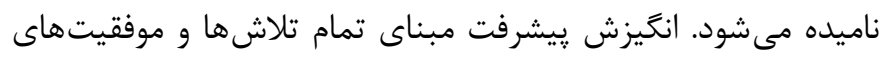

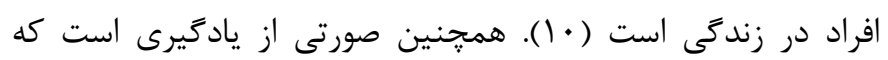

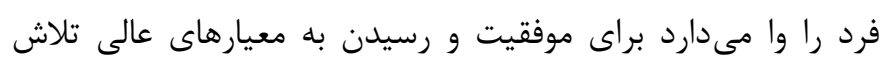

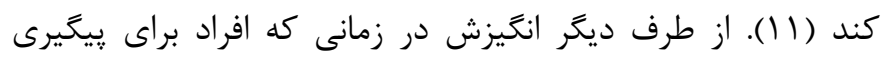

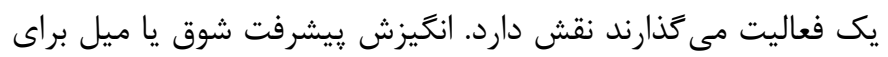
كسب موفقيت است (r ا). انخَيزش پيشرفت، يادكيرى درسى را تسريع

مى كند تا شخص به موفقيت مورد نظرش برسد (r (1).

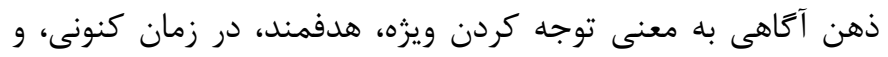

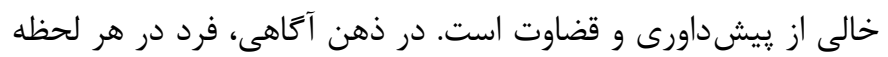

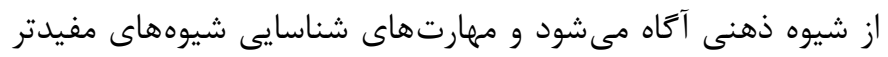

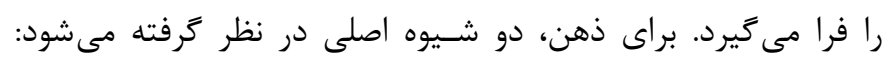

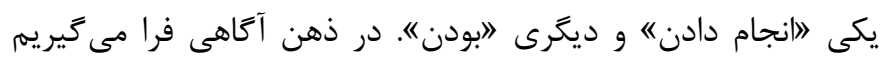

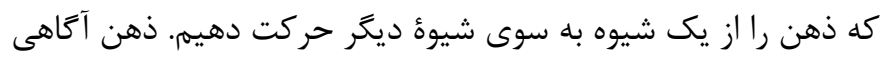
مستلزم راهبردهاى رفتارى، شناختى و فراشناختى ويزه براى متمركز

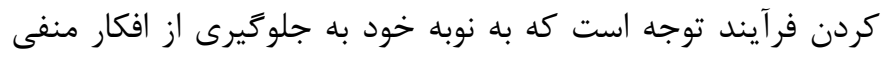
و كاهش نكرانىهاى فزاينده و كمك به شكل گيرى نعاه جديد به زندكى و افكار و هيجانهاى خوشايند منجر مىشود (f) (l). شناخت

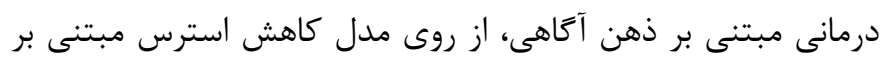

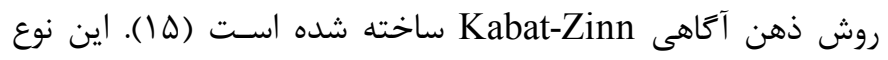

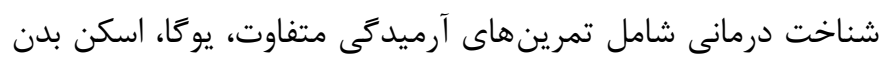

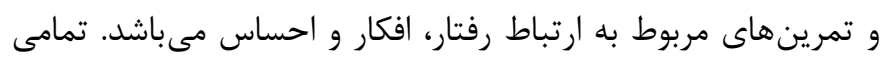

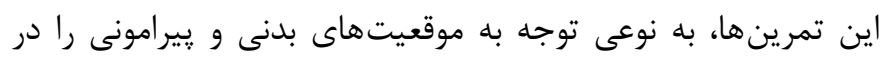

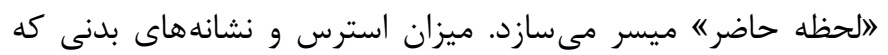
افراد دجار مشكلات يادگيرى تجربه مى كنند بسيار زياد است. آنها به دليل فشارهاى خانواده، محيط تحصيلى و اجتماع دجار اضطرابهاى شديد، كاهش اعتماد به نفس و خودكارآمدى پاييين مىشوند. درمان ذهن آكاهى مىتواند به اين افراد براى تسلط بر بدن خود و كنترل

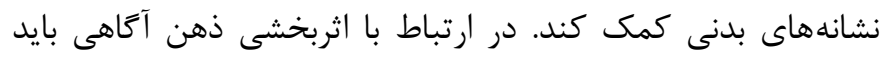

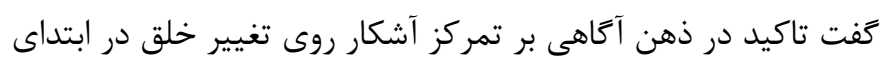

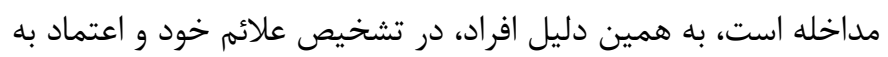

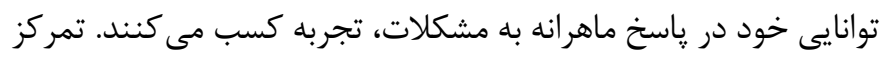
اصلى بر روى تغيير رابطه با افكار، عواطف، و احساسات بدنى نآكاهانه

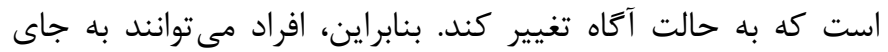

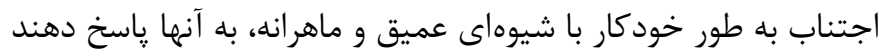

تا جايى كه حل آنها نياز به مداخله مستقيم و مداوم دارد. مشكلات

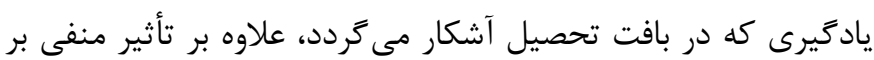

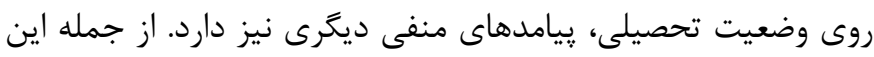

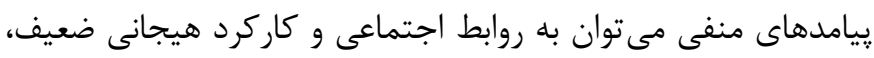

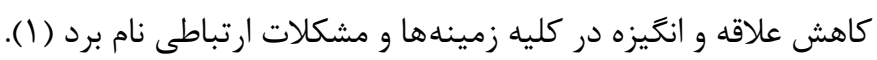

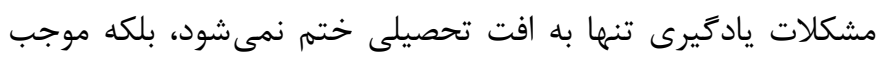

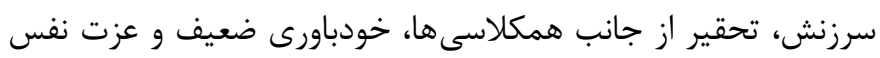

يايين نيز مى شود (r) (r).

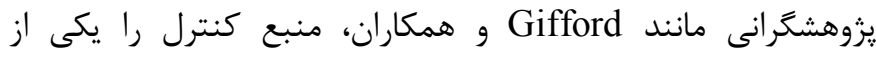
ويزگى هايى مى دانند كه مىتواند سبب موفقيت در تحصيل شود (؟). Weiner

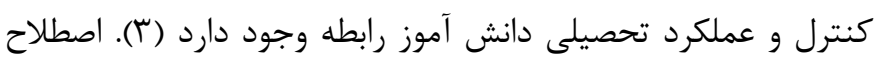
منبع كنترل نشاندهنده دلايلى است كه افراد براى اتفاقات روزمره

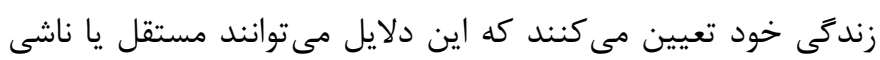

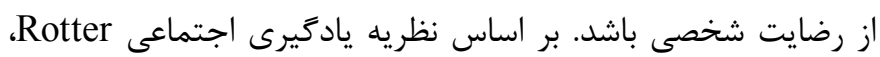

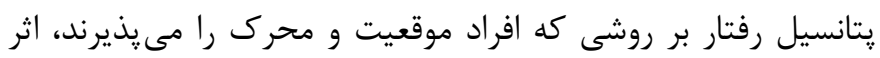
مى كذارد، اما بر اساس انتظارات درى اعمالى كه موجب ارضاى نيازها

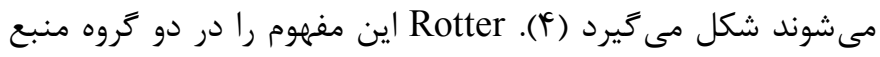

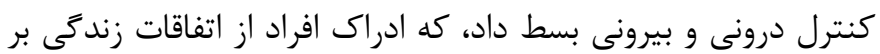

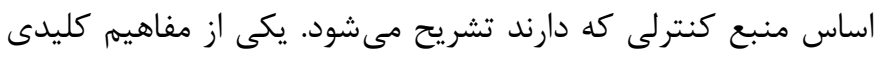

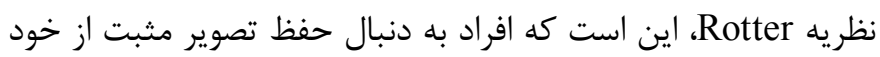

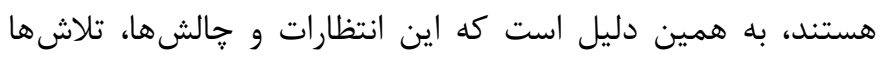

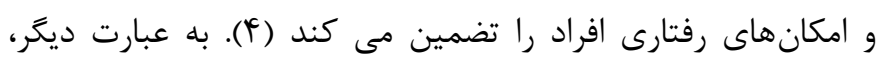

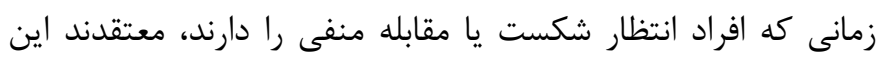

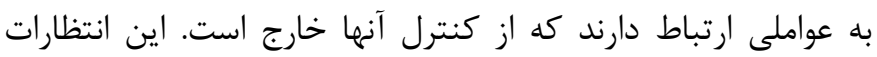

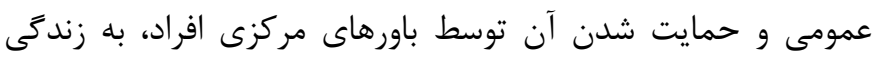

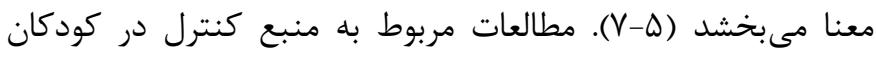
داراى مشكلات يادگيرى نشان مىدهد كه اين كودكان بر اين باورند

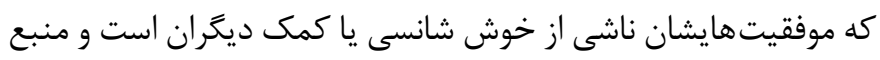
كنترل بيرونى دارند. تحقيقات نشان مى دهند به طور كلى دانش آنس آموزان

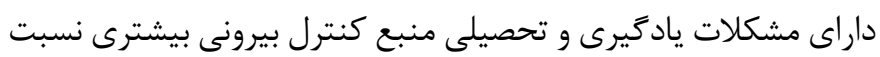

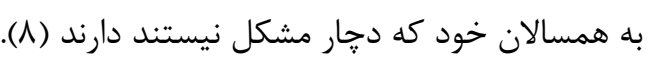

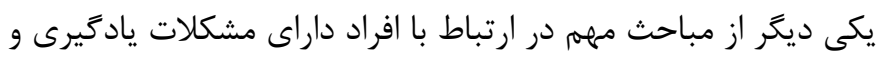

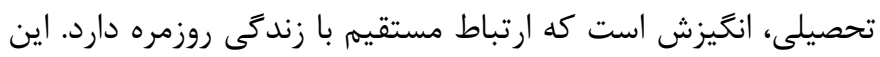
عامل بر عملكرد فردى و اجتماعى افراد اثر مى گذارد. انخيزش عامل مهمى است كه باعث يِيشرفت دانش آموزان مى گردد. تحقيقات نشان داده است كه انخيزه ييشرفت موجب سهولت در يادكيرى مى شود. افراد 
و يايايى اين مقياس در ايران توسط غضنفرى (IIII) با استفاده از

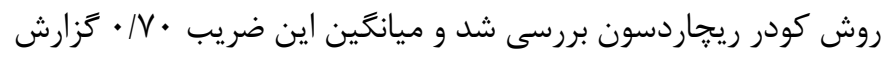

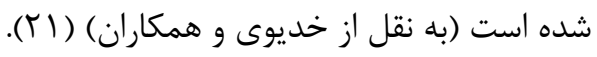

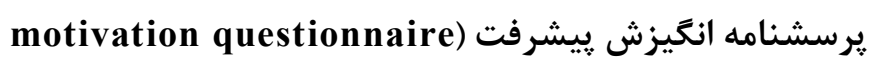

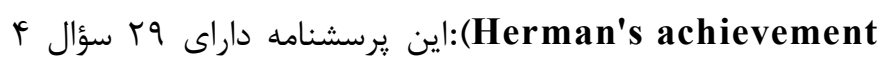

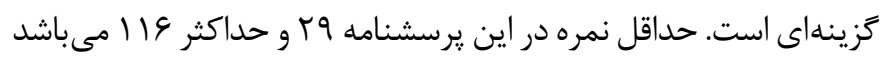

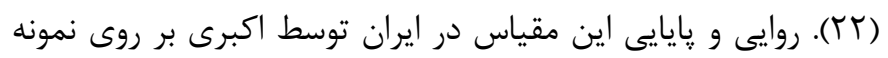

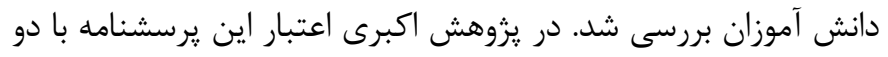

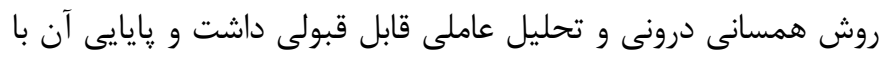

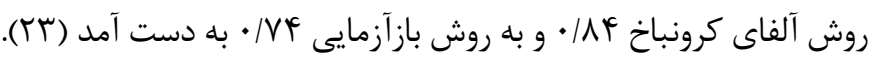

\section{difficulties questionnaire) يرسشنامه مشكلات يادكيرى}

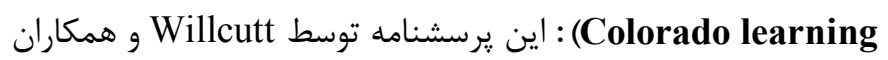

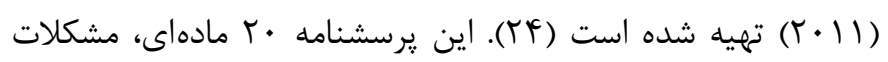

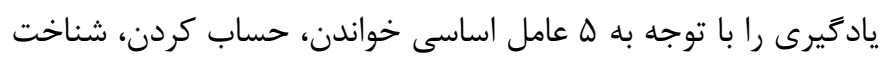

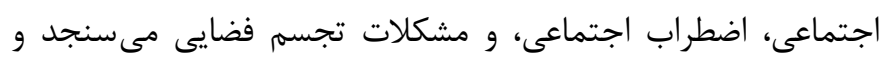

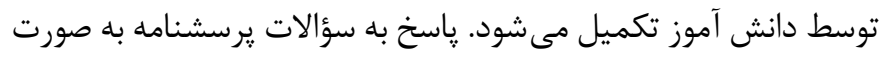

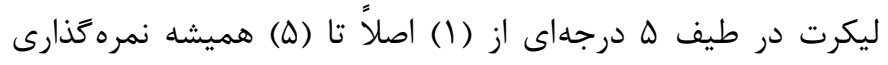

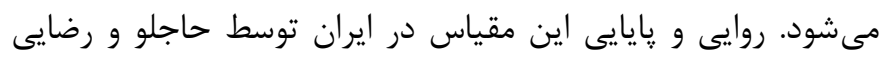

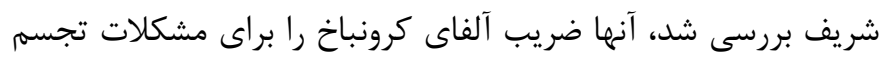

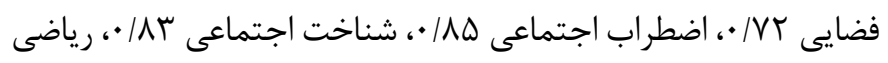

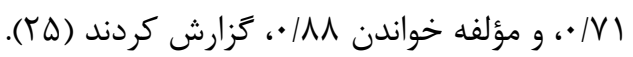

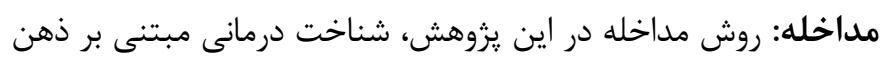

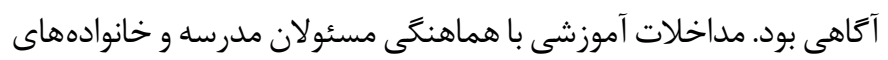

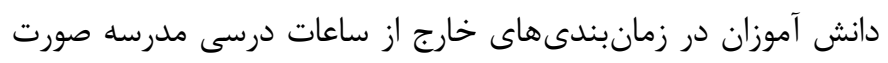

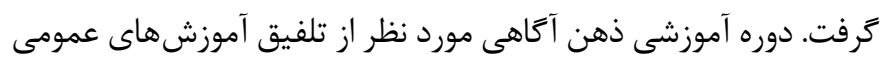

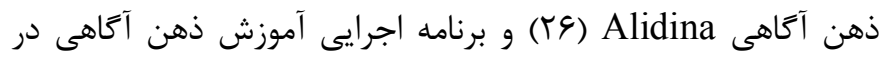

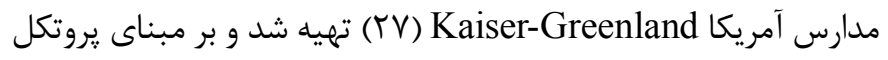

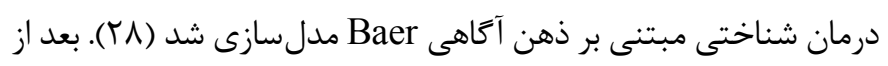

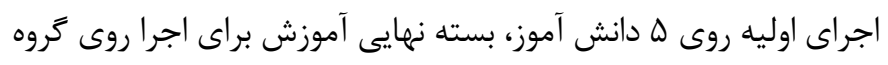

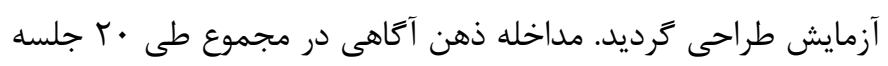

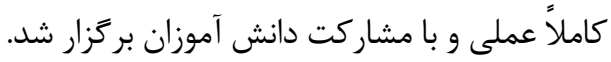

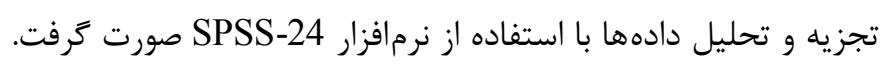

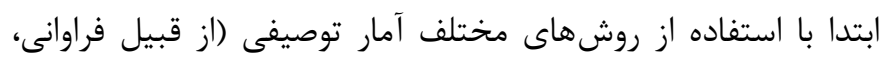

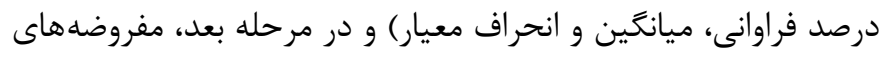

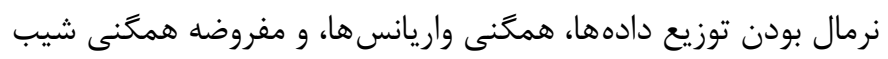

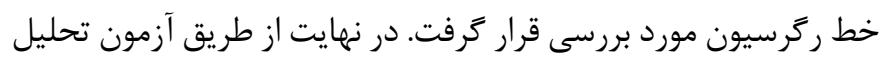

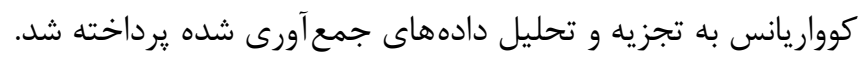

(911)(1). با توجه به ميزان افكار منفى كه در افراد مبتلا به مشكلات

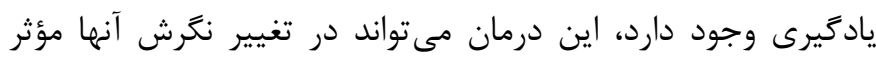

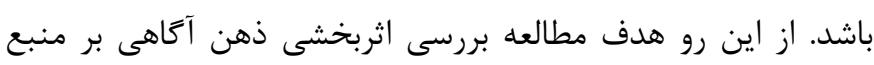

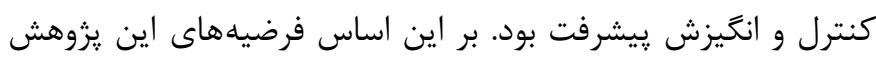

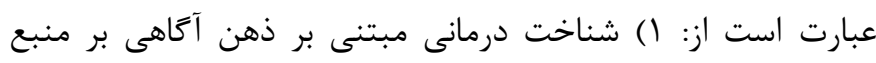

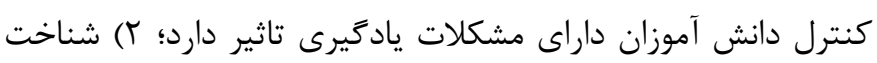

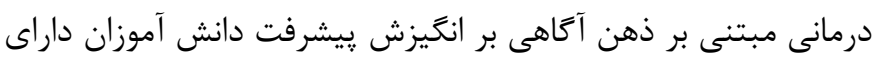
مشكلات يادگيرى تاثير دارد.

\section{روش كار} يروهش حاضر از لحاظ هدف، كاربردى و از نظر ماهيت اجرا و شيوه

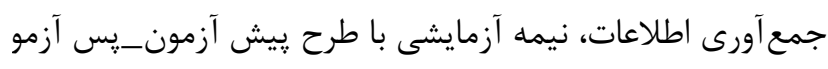

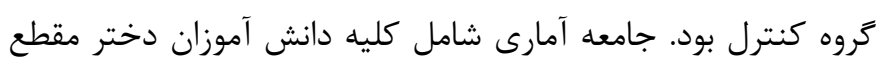

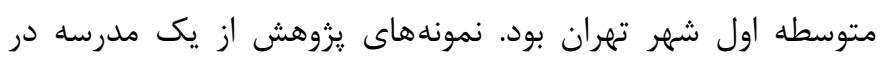

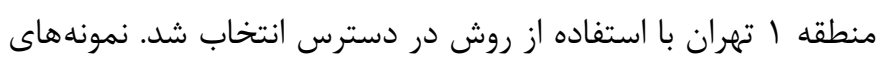

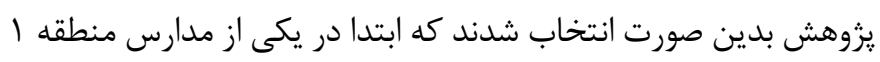

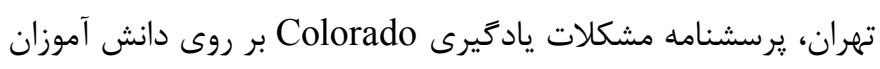

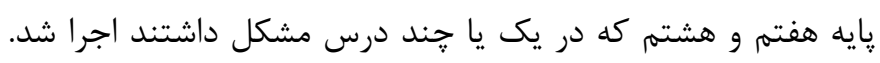

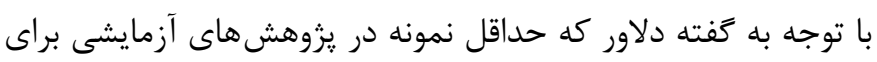

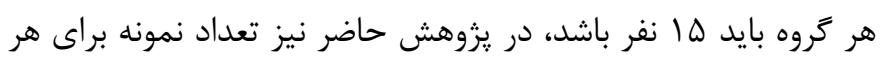

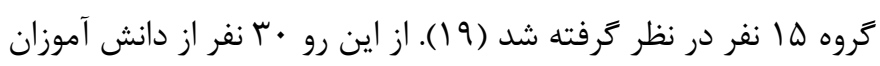

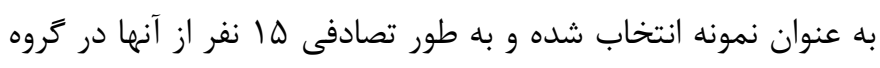

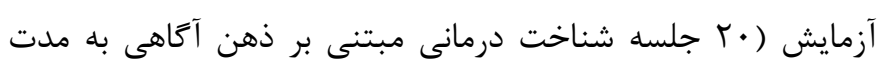

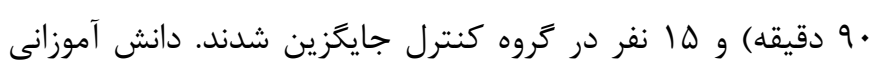
وارد يزوهش شدند كه دختر، مقطع راهنمايى (متوسطه اول)، داراى دري

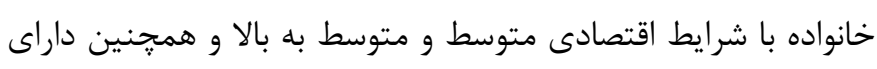
مشكل در يك يا جند درس خاص بودند. سه ماه يس إن از يايان جلسات

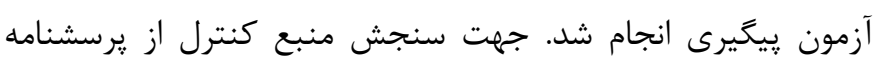

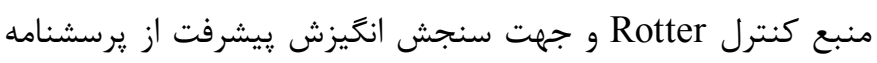
انكَيزش پيشرفت Hermans استفاده شد.

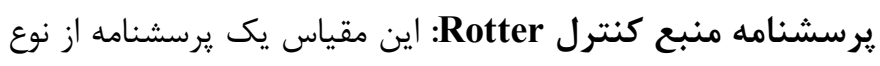

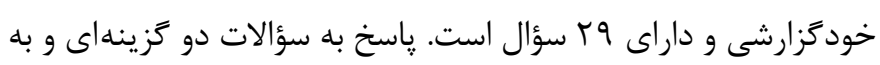
صورت الف و ب تنظيم شده است. آزمودنى بين دو ياسخ يكى رو را انتخاب

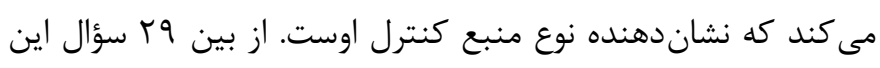

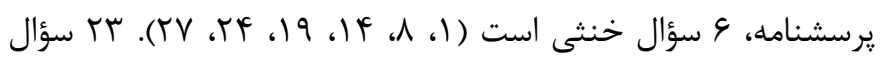

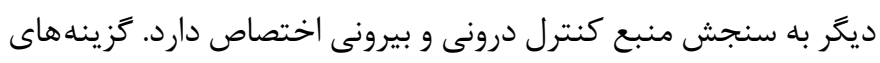

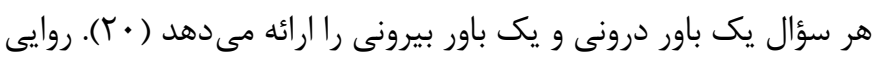


به קِايه هشتم (9 نفر) بود. دامنه سنى دانش آموزان سا تا ها ال سال بود.

بافته ها

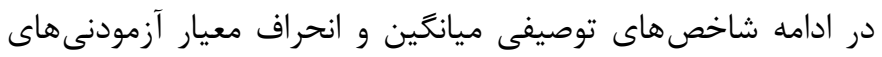
وضعيت كروهها به تفكيك يايه تحصيلى به اين صورت بود كه از ها نفر

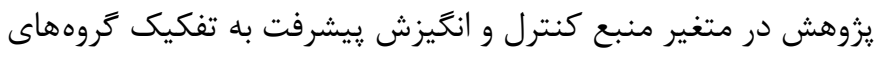
در كروه شناخت درمانى مبتنى بر ذهن آكاهى، بيشترين فراوانى مربوط آزمايش و كنترل در جدول لا ارائه شده است. به پايه هشتم (1 نفر) و از ها نفر كروه كنترل، بيشترين فراوانى مربوط جدول 1. آمارههاى توصيفى متغيرهاى يزوهش در گروه آزمايشى و كنترل در مرحله پٍيش آزمون، پِ آزمون و يِيَيرى

\begin{tabular}{|c|c|c|c|c|c|}
\hline \multicolumn{2}{|c|}{ گروه كنترل } & \multicolumn{2}{|c|}{ آزمايشى } & \multirow{2}{*}{ مر كروه } & \multirow{2}{*}{ متغير } \\
\hline انحراف معيار & ميانگين & انحراف معيار & ميانگين & & \\
\hline$r / \cdot \Lambda$ & 191.9 & $r / M$ & 10/91 & يِش آزمون & \multirow{3}{*}{ منبع كنترل } \\
\hline$r / \cdot V$ & $\mid r / \cdot \cdot$ & T/申. & g/r. & يس آزمون & \\
\hline T/KG & $\mid r / A S$ & $r / \mathcal{H A}$ & $1 / 49$ & ي ريخيرى & \\
\hline$r / 99$ & $r q / \uparrow q$ & $r / \cdot r$ & س rN/r & ِيش آزمون & \multirow{3}{*}{ انخيزش بيشرفت } \\
\hline$r / 9 \Lambda$ & Fq/qu & r/दq & $99 / T 9$ & يس آزمون & \\
\hline T/T & Fq/A. & $4 / 19$ & $G \cdot / V r$ & ييخيرى & \\
\hline
\end{tabular}

فرض صفر مبنى بر همكون بودن شيب رگرسيون پذيرفته مىشود. يس از اطمينان از برقرارى مفروضههاى تحليل كوواريانس تكى متغيرى در بين دادهاى يزوهش، براى آزمون فرضيه نهه، تحليل كوواريانس انجام شد. بر اساس نتايج اين تحليل (جدول ؟)، اجراى مداخله منبع كنترل در دانش آموزان داراى مشكلات يادَيرى را تحتتاثير قرار داده است

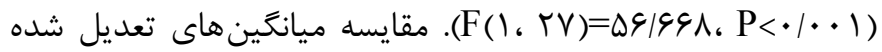
دو گروه شناخت درمانى مبتنى بر ذهن آكاهى و كنترل نشان داد كه اجراى متغير مستقل باعث شده تا ميانگين نمرات منبع كنترل در زروه شناخت درمانى مبتنى بر ذهن آكاهى در مقايسه با زروه كنترل كاهش يابد ( I I I رد و فرض اول يزوهش تاييد شد و جنين نتيجه گيرى شد كه شناخت درمانى مبتنى بر ذهن آكاهى منجر به كاهش ميانگين منبع كنترل دانش آموزان داراى مشكلات يادگيرى مى شود.
نتايج آزمون كولموگروف_اسميرنوف جهت بررسى طبيعى بودن دادهها و به عنوان يكى از ييش فرضهاى تحليل كوواريانس نشان

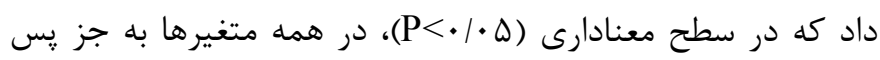
آزمون در گروه شناخت درمانى مبتنى بر ذهن آكاهى و يیيخيرى در گروه كنترل، دادهها نرمال بودند (به مقدار كمى تخطى صورت گرفته شده است كه قابل اغماض است). بنابراين ييش فرض طبيعى بودن رعايت شده است. نتايج آزمون لوين جهت بررسى همگنى واريانس به عنوان يكى ديخر از ييش فرضهاى تحليل واريانس و كوواريانس نشان داد، نتايج بدست آمده براى متغير مستقل شناخت درمانى

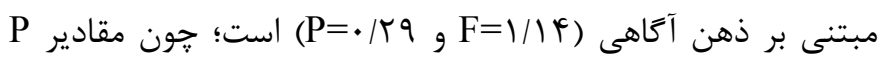

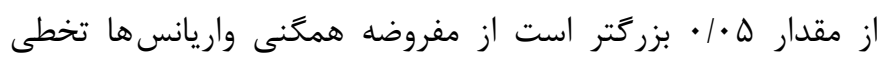
صورت نگرفته است. بررسى همخنى شيب رگرسيون منبع كنترل نشان داد تعامل متغير مستقل شناخت درمانى مبتنى بر ذهن آكاهى

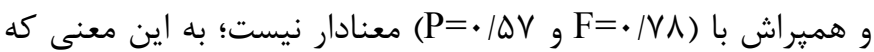

جدول r. نتايج تحليل كوواريانس تك متغيرى در مقايسه منبع كنترل در دو كروه شناخت درمانى مبتنى بر ذهن آكاهى و كنترل

\begin{tabular}{|c|c|c|c|c|c|}
\hline$\eta^{2}$ & $\mathbf{P}$ & $\mathbf{F}$ & ميانگين مجذورات & مجموع مجذورات & منبع تغييرات \\
\hline \multirow{3}{*}{$.19 \mathrm{~V}$} & \multirow{3}{*}{$\cdot|\cdot \cdot|$} & \multirow{3}{*}{$\Delta \varepsilon / 9 \varphi$} & rVQ/A. & rVQ/A. & كروه \\
\hline & & & G/G & $\mid \vee q / \cdot \Delta$ & خطا \\
\hline & & & - & $\Delta \vee q / r q$ & كل \\
\hline
\end{tabular}


ييشرفت در گروه شناخت درمانى مبتنى بر ذهن آحاهى در مقايسه با

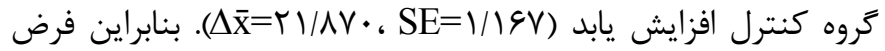
صفر رد و فرض دوم يزوهش تاييد شد و جنين نتيجه گيرى شد كه

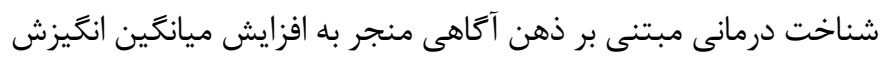
ييشرفت دانش آموزان داراى مشكلات يادگيرى مى شود.
بر اساس نتايج تحليل كوواريانس تك متغيرى در جدول ب، اجراى مداخله انگيزش ييشرفت در دانش آموزان داراى مشكلات يادگيرى را تحت تاثير

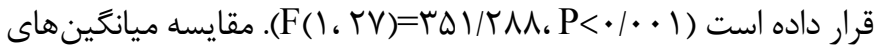
تعديل شده دو گروه شناخت درمانى مبتنى بر ذهن آكاهى و كنترل

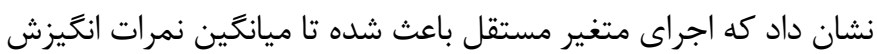

جدول ب. نتايج تحليل كوواريانس تك متغيرى در مقايسه انكَيزش يِيشرفت در دو كروه شناخت درمانى مبتنى بر ذهن آكَاهى و كنترل

\begin{tabular}{|c|c|c|c|c|c|}
\hline$\eta^{2}$ & $\mathbf{P}$ & $\mathbf{F}$ & ميانغين مجذورات & مجموع مجذورات & منبع تغييرات \\
\hline \multirow{3}{*}{. 197} & \multirow{3}{*}{$\cdot \mid \cdot \cdot 1$} & \multirow{3}{*}{ TUI/TA } & $r M g V / \cdot V$ & $r r g V / \cdot V$ & كروه \\
\hline & & & $9 / \Delta \Lambda$ & $r \Delta \Lambda / v q$ & خطا \\
\hline & & & - & $r V \cdot \Delta / r$. & كل \\
\hline
\end{tabular}

مى آموزند اغلب در موقعيتهاى مختلف زندگى ذهن فعال شوند و

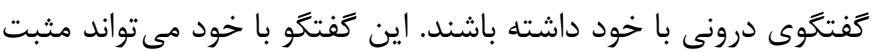
باشد و به فرد شهامت ببخشيد و او را تشويق به انجام كارهاى جديد كند كه در نهايت منجر به افزايش اعتماد درونى به خود مىشود (هَ). همجنين مى توان كفت كه ذهن آكَاهى از طريق تغيير افكار و تصـورات ناسازگار و منفى باعث مى ₹ردد تا در اين دانش آموزان اين منطق بوجود آيد كه بر احساسات، رفتار و شرايط زندگى خود تسلط داشته و بدانند كه شكست و موفقيتهاى آنها نتيجه تلاش خود آنان مى باشد. شكل گيرى جنين نكرشى سبب مى شود كه اين افراد به توانمندى و تلاش خود متكى شده و موجب بهبود اعتماد بنفس در آنها مى گردد، در نتيجه اين امر آنها را از موضع انفعالى در برابر رويدادهاى زندگى مونى دور مى نمايد. با به كارگيرى اين روش مداخلهاى، تصورات منفى و باورهاى غير منطقى كه در دانش آموزان داراى افت تحصيلى مبنى بر خارج از كنترل بودن امور، بدشانس بودن و غيرقابل بيش بينى بودن رويدادهاى زندكى شكل گرفته تصحيح و تغيير يابد و در يى آن موجب افزايش اعتماد بنفس و حس كنترل بر محيط در اين افراد مىشود. نتيجه جنين نكرشى درونى شدن منبع كنترل و نسبت دادن موفقيت ها بــه توانـايىهاى خود خواهد بود (اس، سז). به عبارت ديخر، اين روش افراد را ترغيب مىسازد كه مشاهدهر فرايندهاى ذهنى خود باشند؛ افكار خود انتقادى و قضاوت كننده را ببينند و بيذيرند و سعى در تمركز بر روى آنها نداشته باشند؛ همجنين تأكيد بر پذيرش، خود ممكن است منجر به ارزيابى مجدد افكار ناكارآمد گردد (هऍ). در تبيين فرضيه دوم مى توان كَفت كه تمرينهاى شناختى درمانى مبتنى بر
اين يزوهش با هدف بررسى بررسى اثربخشى شناخت درمانى مبتنى

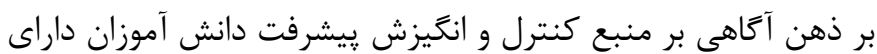
مشكلات يادگيرى انجام شد. نتايج تحليل فرضيههاى يزوهش حاكى از اين بود كه بين ميانگين نمرات يس آزمون منبع كنترل و انخيزش يييشرفت بعد از حذف اثر پيشآزمون براى متغير شناخت درمانى مبتنى بر ذهن آكاهى، تفاوت معنادارى وجود دارد. اين تأثير بدين معنى بود كه يس از اجراى جلسات درمانى، منبع كنترل دانش آموزان از بيرونى به سمت درونى تغيير كرد، همجنين انگَيزش پيشرفت در آنها افزايش يافته است. اين نتايج با يافته هاى يزوهش هاى ابراهيمى و

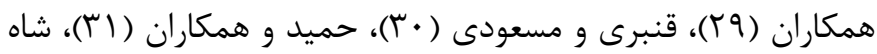
مرادى و انصارى (Tr) و جواهر فروشزاده و سلطانى (rس)) همسو است. بر اساس يزوهش Sulphey ذهن آكاهى ييشبينى كننده منبع كنترل درونى است. به عبارت ديخر، ارتباط ذهن آكاهى و منبع كنترل بيرونى معنادار نيست. افرادى كه مهارت ذهن آكاهى بالاترى دارند، از منبع كنترل درونى بيشترى برخوردارند (YF). در تبيين فرضيه اول مى توان كفت كه افراد با استفاده از روشهاى آرامسازى در لحظه حال زندگى برى كردن را مى آموزند و تأثير آن را در وضعيت روانى خود درك مى كنند

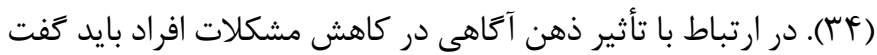
افرا داراى خودآكاهى بالاتر، به دليل داشتن شناخت بيشتر نسبت به توانايى هاى خود بيشتر به خودشان اعتماد دارند و كمتر دجار اضطراب مىشوند. آنها از مسئوليت يذيرى و دقت نظر بالاترى برخوردارند، بر احساسات خود كنترل بيشترى دارند و صادق هستند. مجموع اين عوامل مستقيماً باعث كاهش اضطراب و مديريت خود مىشود. آنها 
كرد كه نمونه هاى يزوهشى از ميان دانش آموزان منطقه يك تهران كه جزو مناطق مرفه از لحاظ مادى و موقعيت اجتماعى بودند انتخاب شدند، لذا در تعميم نتايج يزوهش بايد احتياط كرد. با توجه به اينكه

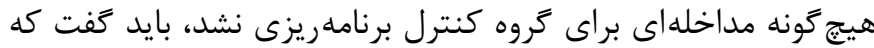

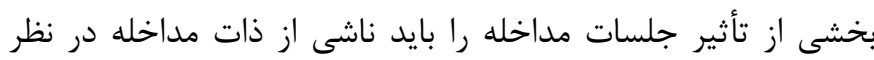

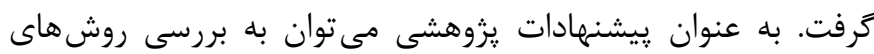

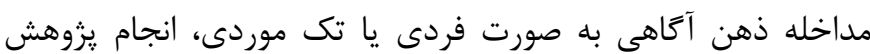

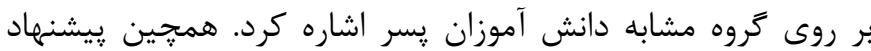
مىشود آموزش مهارتهاى ذهن آكاهى به معلمان آموزش داده شود نا از اين راهبردها در كلاس درس به منطور ارتقاى عملكرد دانش

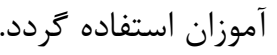

\section{نتيجه كَيرى}

آموزش ذهن آكاهى به دانش آموزان داراى مشكلات يادگيرى،

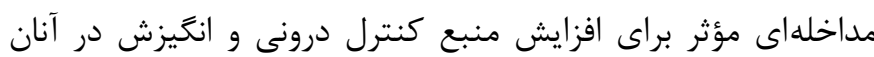

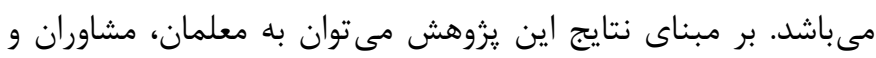

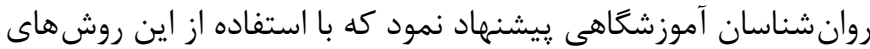
درمانى در بهبود مهارت هاى فردى و يادگيرى دانش آموزان بكوشند.

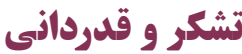

بر خود لازم مى دانيم از تمام كسانى كه در انجام اين يزوهش ياور و همراهمان بودند، بهخصوص كودكان استثنايى و خانوادهاى آنان آنان

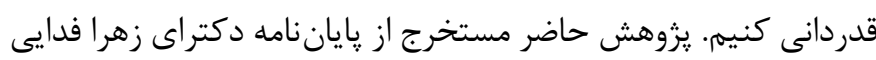

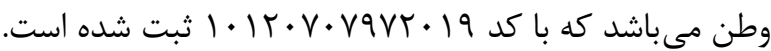

\section{References}

1. Waber DP. Rethinking learning disabilities: Understanding children who struggle in school. New York:Guilford Press; 2010.

2. Gifford DD, Briceno-Perriott J, Mianzo F. Locus of control: Academic achievement and retention in a sample of university firstyear students. Journal of College Admission. 2006;191:18-25.

3. Weiner B. Motivation from an attribution perspective and the social psychology of perceived competence. In Elliot AJ, Dweck CS, editors. Handbook of competence and motivation. New York:Guilford Press;2005. pp. 73-84.
ذهن آكاهى با بالا رفتن انخيزه افراد در لحظهُ حال از طريق فنونى مثل توجه به تنفس و بدن و توجه دادن آكاهى به اينجا و اكنون بر نظام شناختى و يردازش اطلاعات اثر مى گذارد (س世). به عبارت ديخر، اتر افراد شناخت كافى در خصوص توانايى خود بيابند و موقعيتهاى خود

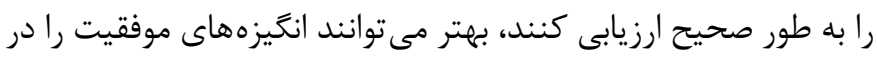

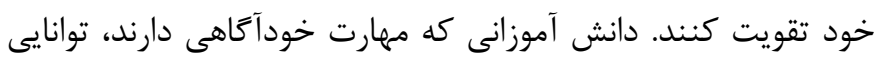
بيشترى جهت درى خواستههاى ديگران دارند و به خوبى مى توانند فشار همسالان را دريابند. با اكتساب اين مهارت تغييرات جشمخيرى در شاخصهاى فردى و بين فردى دانش آموزان ايجاد مىشود، به نحوى كه آنها به ادراك واقعبينانه نسبت به خود و جهان ييرامون دست مى يابند و در كنترل احساسات و رفتارها توانمند مى شوند، همجنين در برقرارى روابط مؤثر و عميق و صادقانه با ديخران توفيق بيشترى مى يابند. افزون بر آن با بهبود خود آكاهى، كاركردهاى هوشى مانند

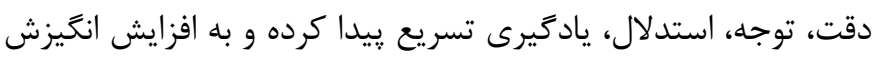
تحصيلى نيز منجر مى شود (Y). شايان ذكر است كه نمرات ييخيرى نسبت به يس هـ آزمون تا حدودى افت داشت. يس از يايان جلسات، برخى از تمرين هاى سادهتر انتخاب شد و به صورت يَيج در اختيار آزمودنى ها و خانوادههاى آنها گذاشته شد تا به صورت هفتخىى تمرينات را ادامه دهند. اما اين مسئله مورد توجه آنها قرار نكرفت و اين دليل افت نمرات اين بود. از محدوديتهاى يزوهش حاضر مى توان به نامنظم بودن برخى از آزمودنى ها كه سبب شروع با تاخير جلسات مىشد، تحمل كم والدين و توقع نتيجه سريع، و استفاده از مقياس هاى خودگزارشى كه همانند ديخر يزوهش ها در

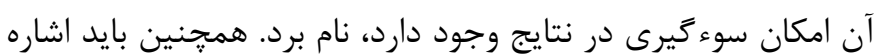

4. Rotter JB. Some comments on the "Cognates of personal control". Applied and Preventive Psychology. 1992:1(2):127-129.

5. Farrell M. Foundations of special education: An introduction. New Jersey:John Wiley \& Sons;2009.

6. Hassan AE. Emotional and behavioral problems of children with learning disabilities. Journal of Educational Policy and Entrepreneurial Research (JEPER). 2015;2(10):66-74.

7. Angelova NV. Locus of control and its relationship with some social-demographic factors. Psychological Thought. 2016;9(2):248-258 
8. Shogren KA, Bovaird JA, Palmer SB, Wehmeyer ML. Locus of control orientations in students with intellectual disability, learning disabilities, and no disabilities: A latent growth curve analysis. Research and Practice for Persons with Severe Disabilities. 2010;35(3-4):80-92.

9. Yousefi Y, Farokhi N. A meta-analysis of factors affecting educational motivation. Educational Measurement. 2013;13(4):133168. (Persian)

10. Lieberman DA, Remedios R. Do undergraduates' motives for studying change as they progress through their degrees?. British Journal of Educational Psychology. 2007;77(2):379-395.

11. Wigfield A, Eccles JS, Schiefele U, Roeser RW, Davis-Kean P. Development of achievement motivation. In: Wigfield A, Eccles JS, Schiefele U, Roeser RW, Davis-Kean P, editors. Handbook of child psychology. New Jersey:Wiley;2007.

12. Seif A. Modern educational psychology: Psychology of learning and instruction. Tehran:Dowran Publication;2011. (Persian)

13. Karimi Y. Educational psychology. Tehran:Arasbaran Publication;2008. (Persian)

14. Segal ZV, Williams JM, Teasdale JD. Mindfulness-based cognitive therapy for depression. 2nd ed. New York:Guilford Press;2018 .

15. Kabat-Zinn J. Mindfulness-based interventions in context: past, present, and future. Clinical Psychology: Science and Practice. 2003;10(2):144-156.

16. Mikaeili N. Comparison of thought control, mindfulness and attachment styles in students with high and low tendency to addiction. Research on Addiction. 2017;10(40):65-86. (Persian)

17. Hayes SC, Hofmann SG. The third wave of cognitive behavioral therapy and the rise of process-based care. World Psychiatry. 2017;16(3):245-246.

18. Omidi A, Mohammadkhani P, Mohammadi A, Zargar F. Comparing mindfulness based cognitive therapy and traditional cognitive behavior therapy with treatments as usual on reduction of major depressive disorder symptoms. Iranian Red
Crescent Medical Journal. 2013;15(2):142-146.

19. Delavar A. Foundations of theoretical and practical research in humanities and social sciences. Tehran:Roshd Publication;2015. (Persian)

20. Rotter JB. Generalized expectancies for internal versus external control of reinforcement. Psychological Monographs: General and Applied. 1966:80(1):1-28.

21. Khadivi A, Vakili Mafakheri A. A Survey of relationship between achievement motivation, locus of control, self-concept and high school first grader science students academic achievement the five regions of Tabriz. Journal of Instruction and Evaluation. 2011;4(13):45-66. (Persian)

22. Hermans HJ. A questionnaire measure of achievement motivation. Journal of Applied Psychology. 1970:54(4):353-363.

23. Akbari B. Validity and reliability of Herman's Achievement Motivation Test on the Guilan's high school students. Research in Curriculum Planning. 2008;16(1):73-96. (Persian)

24. Willcutt EG, Boada R, Riddle MW, Chhabildas N, DeFries JC, Pennington BF. Colorado Learning Difficulties Questionnaire: validation of a parent-report screening measure. Psychological Assessment. 2011;23(3):778-791.

25. Hajloo N, Rezaie Sharif A. Psychometric properties of Colorado Learning Difficulties Questionnaire (CLDQ). Journal of Learning Disabilities, 2012;1(1):24-43. (Persian)

26. Alidina S, Marshall JJ. Mindfulness workbook for dummies. New Jersey:John Wiley \& Sons;2013.

27. Kaiser-Greenland S, Flook L, Smalley S, Locke J, Ishijima E, Kasari C. Effects of mindful awareness practices on executive functions in elementary school children. Journal of Applied School Psychology. 2010:26:70-95.

28. Baer RA. Mindfulness-based treatment approaches: Clinician's guide to evidence base and applications. Amsterdam:Elsevier;2015.

29. Ebrahimi E, Naemi AM, Rashid H. The relationship between mindfulness and locus of control with marital satisfaction of Sabzevar high school teachers. 3rd National Conference of Mental Health and Well-being. 2015 March 11-12; Quchan, 
Iran. (Persian)

30. Ghanbari P, Masoudi S. The effectiveness of teaching cognitive based mindfulness on early maladaptive schemes, locus of control and emotional cognitive adjustment of students in Neyshbour. 4th National Conference of Counseling and Mental Health. 2016 May 3-4. Quchan, Iran. (Persian)

31. Hamid N, Eidi Baygi M, Ataie Moghaloo V, Matlabi S. The effectiveness of Cognitive-Behavioral Group Therapy Based on Rational emotive therapy on locus of control and academic achievement of medical students. Journal of Research in Educational Systems. 2015;7(22):191-207. (Persian)

32. Shahmoradi Tabatabaei T. Ansari Shahidi M. Effectiveness of mindfulness of achievement motivation of high school girls.
The 1st International Conference on Culture, Psychopathology and Education. 2017 May 3-4. Tehran, Iran. (Persian)

33. Javaherforushzadeh M. Soltani Kouhbanani Sh. The effectiveness of training mindfulness skills on motivational structures among girl students. Journal of Fundamentals of Mental Health. 2016;18(Special Issue):436-440. (Persian)

34. Sulphey M. Is mindfulness a predictor of locus of control?. Journal of Applied Management and Investments. 2016;5(2):121-130. 35. Mezulis AH, Hyde JS, Abramson LY. The developmental origins of cognitive vulnerability to depression: Temperament, parenting, and negative life events in childhood as contributors to negative cognitive style. Developmental Psychology. 2006;42(6):1012-1025. 